\title{
Epigenetic actions of environmental factors and promising drugs for cancer therapy (Review)
}

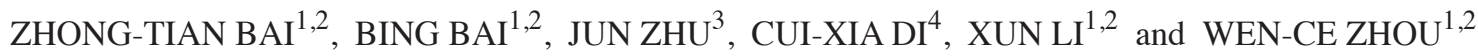 \\ ${ }^{1}$ The Second Department of General Surgery, Key Laboratory of Biotherapy and Regenerative Medicine, First Hospital of \\ Lanzhou University; ${ }^{2}$ Hepatopancreatobiliary Surgery Institute of Gansu, Medical College Cancer Center of \\ Lanzhou University; ${ }^{3}$ Pathology Department of Donggang Branch Courts, First Hospital of Lanzhou University; \\ ${ }^{4}$ Department of Heavy Ion Radiation Medicine, Institute of Modern Physics, \\ Chinese Academy of Sciences, Lanzhou, Gansu 730000, P.R. China
}

Received January 19, 2016; Accepted June 9, 2017

DOI: $10.3892 / \mathrm{ol} .2017 .7597$

\begin{abstract}
Carcinogenesis is known to be primarily associated with gene mutations. Recently, increasing evidence has suggested that epigenetic events also serve crucial roles in tumor etiology. Environmental factors, including nutrition, toxicants and ethanol, are involved in carcinogenesis through inducing epigenetic modifications, such as DNA methylation, histone deacetylase and miRNA regulation. Studying epigenetic mechanisms has facilitated the development of early diagnostic strategies and potential therapeutic avenues. Modulation at the epigenetic level, including reversing epigenetic modifications using targeted drugs, has demonstrated promise in cancer therapy. Therefore, identifying novel epigenetic biomarkers and therapeutic targets has potential for the future of cancer therapy. The present review discusses the environmental factors involved in epigenetic modifications and potential drug candidates for cancer therapy.
\end{abstract}

\section{Contents}

1. Introduction

2. Epigenetic modifications

3. Environment factors and the how to influence epigenetic modifications

4. Epigenetic modifications and inhibitors

Correspondence to: Professor Wen-Ce Zhou, The Second Department of General Surgery, Key Laboratory of Biotherapy and Regenerative Medicine, First Hospital of Lanzhou University, 1 Donggang West Street, Lanzhou, Gansu 730000, P.R. China

E-mail: zhouwc129@163.com

Abbreviations: PTM, post translational modification; HDAC, histone deacetylase; DNMT, DNA methyltransferase; VPA, valproic acid; NGS, next generation sequencing; HMT, histone methyltransferases; LSD, lysine-specific demethylase

Key words: epigenetic modification, environmental factor, promising drug, cancer therapy
5. Novel drug exploration using the old-fashioned 'Drug repositioning' method

6. Summary

\section{Introduction}

Currently, cancer is a major threat human health worldwide. Carcinogenesis is a multi-step process resulting mainly from the activation of oncogenes and the deactivation of tumor-suppressor genes. Etiologically, emerging evidences have demonstrated that epigenetic mechanisms are equally vital to carcinogenesis (1), including the chemical modifications of DNA and histone proteins, post-transcriptional regulation of microRNAs (miRNA)s and associated signaling pathways (2). Epigenetic modifications have been suggested to be a nearly event in carcinogenesis, and maybe useful as potential targets for early diagnosis, cancer treatment and prognosis evaluation (3). Based on the increasing number of studies, the focus of investigations of carcinogenesis mechanisms have also shifted from the genetic to epigenetic (4). Epidemiologically, epigenetic mechanisms are stressed by foreign substances, including xenobiotics and environmental conditions (5). Identifying an association between environmental factors and tumorigenesis may enable the development of personalized epigenetic medicines. In the present review, the environmental factors involved in epigenetic actions of carcinogenesis and the recent advancements in epigenetic drugs for cancer treatment are summarized.

\section{Epigenetic modifications}

Epigenetic modifications are defined as heritable alterations of gene expression levels induced by environment-gene interactions, including DNA methylation, DNA hydroxy methylation, histone modifications, non-coding RNA and miRNA (1). The manifestations of epigenetic alterations are various post-translational modifications (PTMs), including acetylation, methylation, phosphorylation and ADP-ribosylation (6). PTMs drive local changes in chromatin structure and allow for selective access of transcriptional machinery to the DNA. They can also induce various types of signals, subsequently 


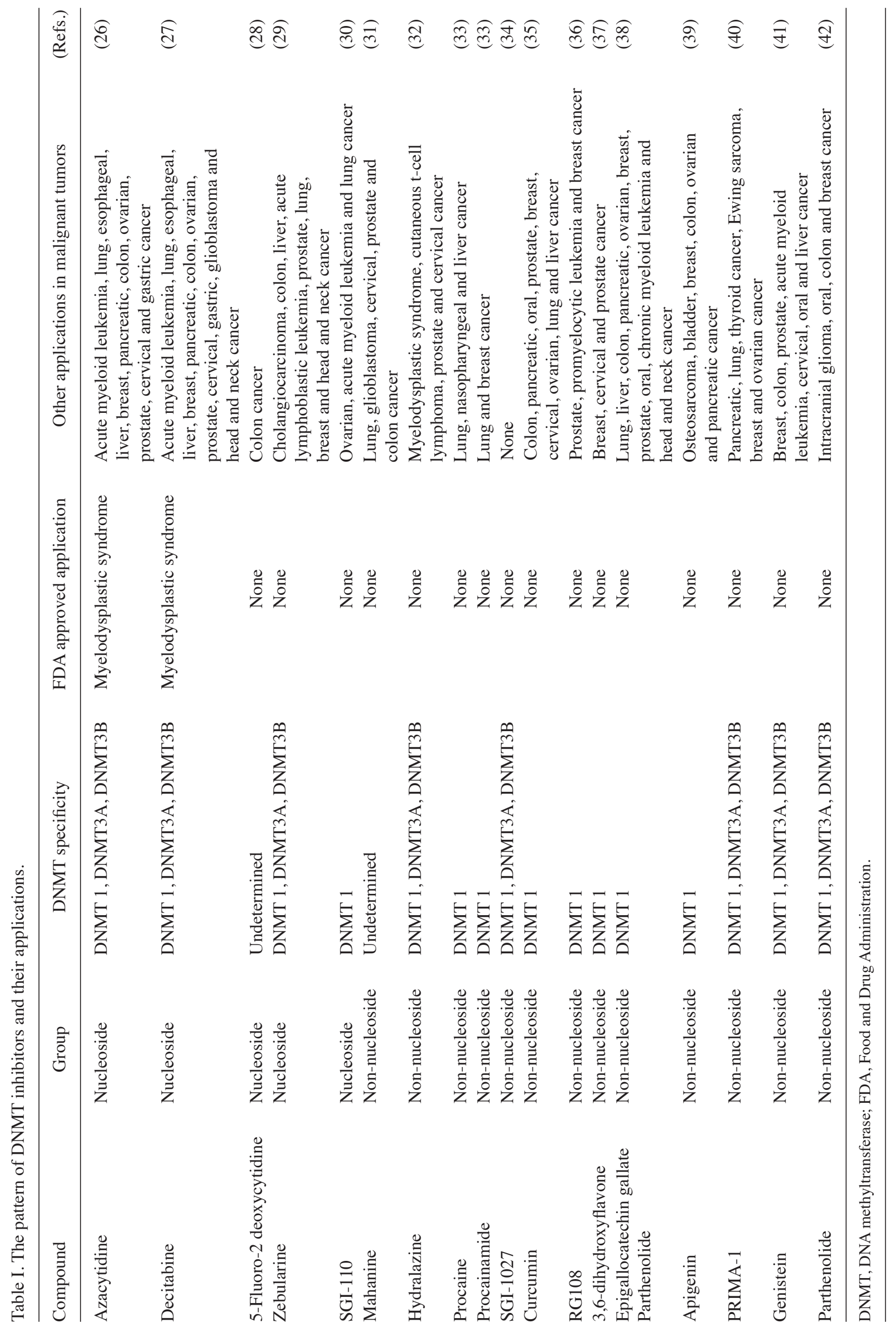




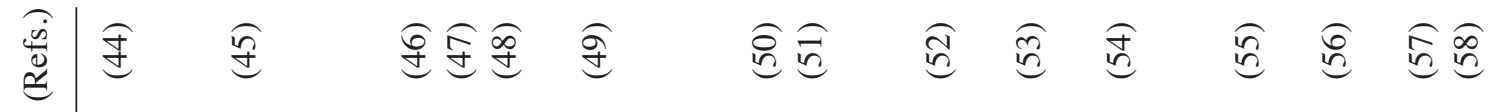

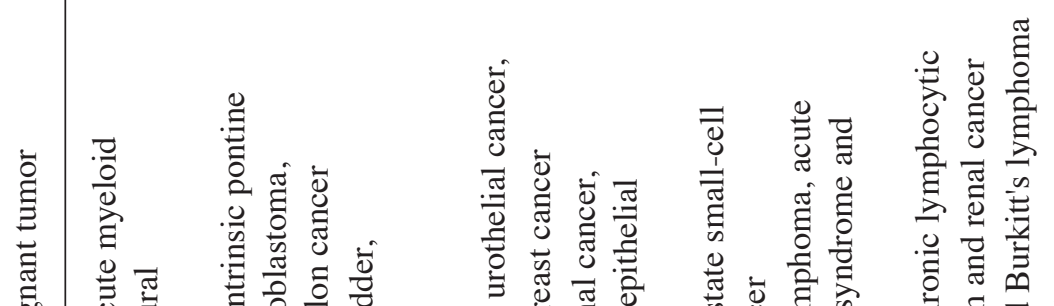

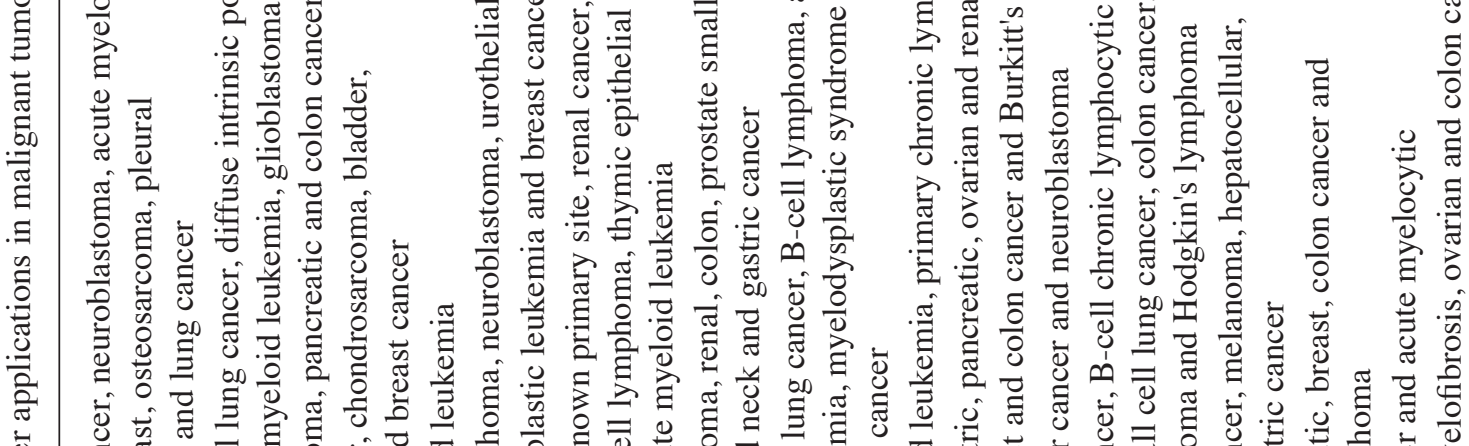

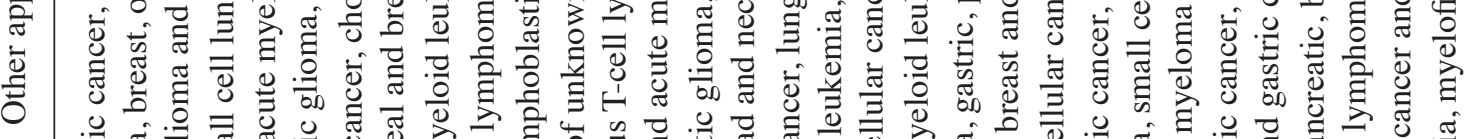

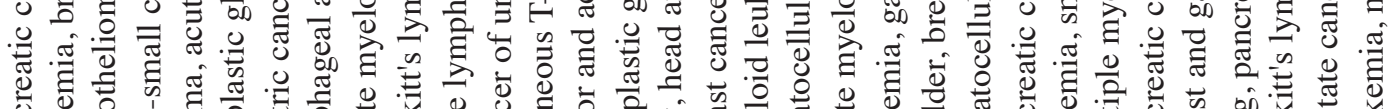

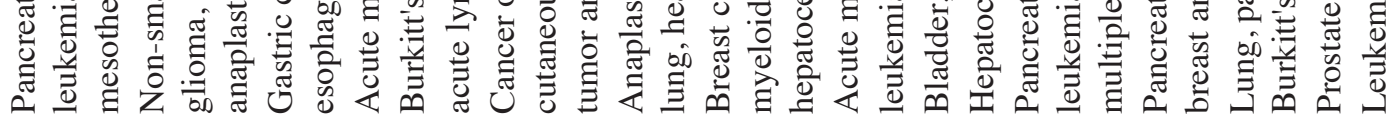

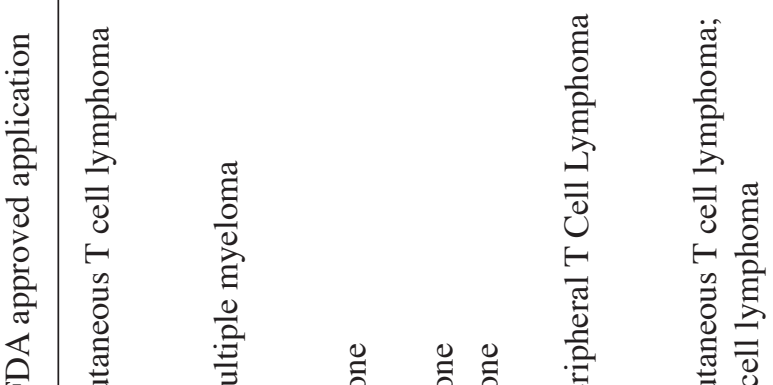

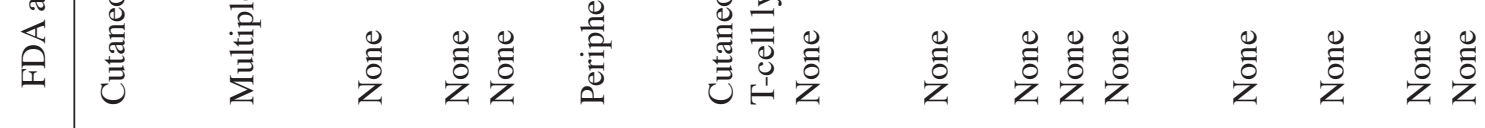

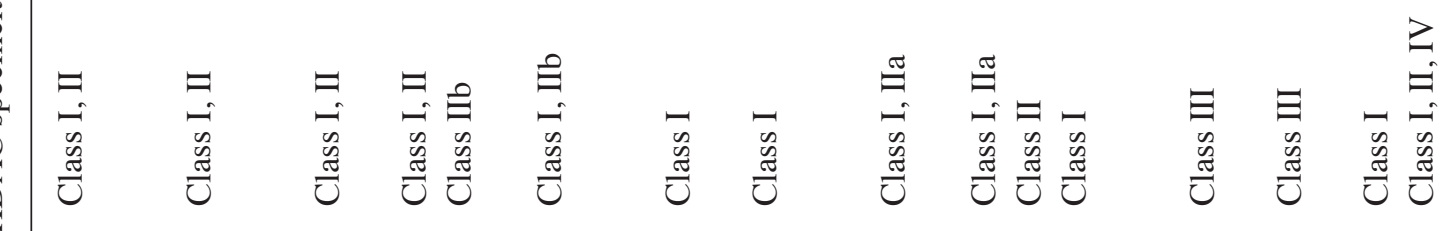
幽 
activating mechanisms that induce specific cellular responses to the environment (7).

\section{Environment factors and the how to influence epigenetic modifications}

Epidemiologically, the majority of environmental factors, including geographical regions, stress, nutrition and toxicants, affect malignant diseases by inducing epigenetic modifications (8). Additionally, the environmental factors include race, climate, life style, diet, nutritional factors (9), airborne polycyclic aromatic hydrocarbons (10), toxicants (e.g., cocaine) (11), alcohol (5), fungicides or pesticides (e.g., dicofol and vinclozolin) (12), aflatoxin (13), bacteria (e.g., Helicobacter Pylori), viruses (e.g., hepatitis virus) (14), heavy metal exposure (e.g., cadmium, arsenic) (15) and endocrine disruptors (e.g., bisphenol-A) (16).

Previous studies have demonstrated that the majority of environmental factors have the ability to interfere with DNA methylation by altering the availability of the methyl donor or the activity of DNA methyltransferases (DNMTs) (17). Compounds in the environment, including the endocrine disruptors (e.g., diethylstilbestrol), tobacco and ethanol, may induce epigenetic modification (18). Dysplasia and sudden exposure in the critical stage (e.g., early development) to environmental factors promotes disease occurrence in adults (19). Environmental factors may permanently change the epigenetic genome and gene expression levels, and result in alterations of phenotypes and susceptibility to disease (19).

Evidence from liver cancer tissue samples revealed that ethanol altered the methylation status of histone $\mathrm{H} 3$ at two lysine residues (e.g., lys-4/9) and increased the phosphorylation of histone H3 at two serine residues (e.g., ser-10/28) (5). Chronic ethanol uptake may result in upregulation of certain miRNAs (miR-34a, miR-107 and miR-122), which can also alter the methylation pattern of DNA in liver tumors, thereby affecting gene expression levels (20). Taken together, histone modification, DNA methylation and miRNA may produce a synergistic effect in ethanol-associated tumors. It was reported that the hepatitis $\mathrm{B}$ virus $\mathrm{X}$ protein may induce aberrant epigenetic modifications in human hepatocellular carcinoma by inducing the DNA hypermethylation of tumor suppression genes (21), promotion-associated gene-specific DNA hypomethylation, histone acetylation or deacetylationand alterations of miRNAs (22).

Epigenetic modifications serve an important role in cancer development; the deregulation of this has been identified as a feature of cancer initiation (3). Investigating the underlying mechanisms may aid the development of specific therapeutic targets and personalized epigenetic medicines (23). Epigenetic drugs have emerged as potential agents for cancer treatment (Tables I and II).

\section{Epigenetic modifications and inhibitors}

Evidence has demonstrated that histone modifications together with DNA methylation constitute an 'epigenetic code', which regulates transcriptional status and disruptscode writing or interpretation (23). These aberrant alterations to the code may activate the expression of oncogenes, including c-Myc,
Table III. Promising epigenetic inhibitors.

\begin{tabular}{lllr}
\hline Drug & \multicolumn{1}{c}{ Inhibitor Type } & \multicolumn{1}{c}{ Targets } & (Refs.) \\
\hline BIX-01294 & HMT(G9a) & H3K9me2 & $(59)$ \\
UNC0638 & HMT(G9a) & H3K9me2 & $(60)$ \\
GSK126 & HMT(EZH2) & H3K27 & $(61)$ \\
EPZ5676 & HMT(DOT1L) & H3K79 & $(62)$ \\
OG-L002 & HMT(LSD1) & MAO-A and B & $(63)$ \\
ORY-1001 & HMT(LSD1) & LSD1 & $(64)$ \\
---- & HMT (Jumonji C) & LSD1 & $(65)$ \\
\hline
\end{tabular}

HMT, histone methyltransferases; LSD, lysine-specific demethylase; EZH2, enhancer of zeste 2 polycomb repressive complex 2 subunit; DOT1L, DOT1 like histone lysine methyltransferase.

which promotes the development of specific small molecule modulators of histone binding proteins (24). A few of these compounds have been used in clinical development for tumor therapy, Tables I and II summarized the current reported epigenetic inhibitors.

DNMTs, including DNMT1, DNMT3A and DNMT3B, catalyze a methyl group transformation from the methyl donor S-adenosylmethionine to the $\mathrm{C}-5$ of cytosine in DNA. In malignant cells, hypermethylation at the $\mathrm{CpG}$ island induces suppression of numerousvital tumor suppressor genes, including p16 (25). Thus, small molecules targeting DNMTs may potentially reverse epigenetic silencing of cancer suppressor genes in a number of different cancer types. The DNMT inhibitors were used in tumor clinical treatments, including azacitidine, decitabine and SGI-110 (others are presented in Table I and Fig. 1) (26-42). These compounds demonstrated good anti-proliferative effects in various cancer cell lines, including breast, prostate, lung, pancreas, liver and leukemia (23). However, the practical utility in clinics has been limited by systemic toxicity and off-target effects, including in certain heme malignancies.

The other major category is the histone deacetylase (HDACs) inhibitor, which enables the catalysis of $\mathrm{N}$-acetyl residues hydrolysis in histones and activation of histone acetyl transferases. A previous study revealed that HDACs serve roles as crucial mediators in tumor survival and progression (43). A total of four HDAC inhibitors were approved by the Food and Drug Administration (FDA): Vorinostat, belinostat, panobinostat and romidepsin (details are presented in Table II and Fig. 1) (44-58).

Following the development of epigenetic drugs, second-generation epigenetic inhibitors emerged, including histone methyltransferase inhibitors, euchromatic histone lysine methyltransferase 2 (G9a) inhibitors, enhancer of zeste 2 polycomb repressive complex 2 subunit inhibitors, DOT1 like histone lysine methyltransferase inhibitors, histone demethylases and Jumonji C inhibitors (Table III and Fig. 1) (59-64). These epigenetic clinical agents have intrinsically greater binding specificity to their molecular targets and may be developed as drugs for malignant disease.

Valproic acid (VPA; valproate), an acidic chemical compound, was mainly used in the treatment of epilepsy, 

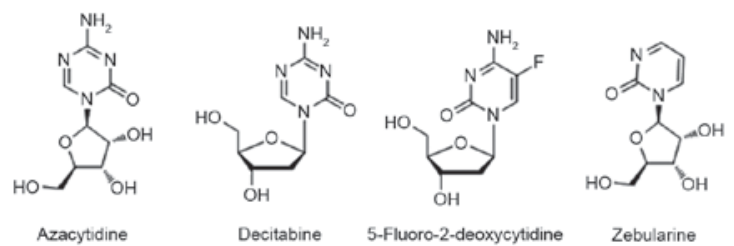<smiles>CCC(CC)OC(=O)NNCCO</smiles>

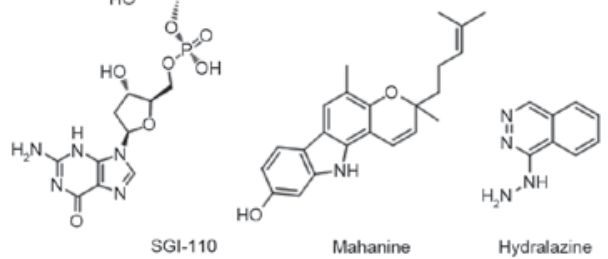<smiles>CCN(CC)CCOC(=O)c1ccc(N)cc1</smiles><smiles>Cc1cc(Nc2ccc(NC(=O)c3ccc(N(C)Cc4cncc5ccccc45)cc3)cc2)nc(N)n1</smiles><smiles>CCC(=O)/C=C/c1ccc(O)c(OC)c1</smiles><smiles>O=C(OC1Cc2c(O)cc(O)cc2OC1c1cc(O)c(O)c(O)c1)c1cc(O)c(O)c(O)c1</smiles>

SGI-1027

Curcumin<smiles>O=C(O)CC(Cc1c[nH]c2ccccc12)N1C(=O)c2ccccc2C1=O</smiles><smiles>O=c1c(O)c(-c2ccccc2)oc2ccc(O)cc12</smiles>

RG108

3,6-dihydroxyflavone

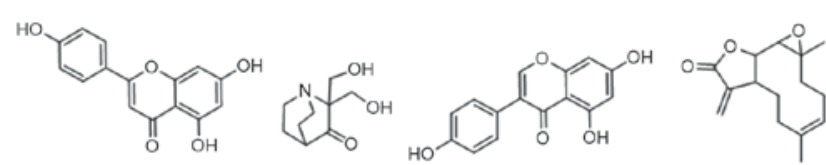<smiles>Nc1ccc(C(=O)NCCN2CC3CCCC2C3)cc1</smiles><smiles>Cc1nc2ccccc2c(CCNCc2ccc(/C=C/C(=O)NO)cc2)c1C</smiles><smiles>CC(/C=C/C(=O)NO)=C\C(C)C(=O)c1ccc(N(C)C)cc1</smiles><smiles>O=C(O)/C=C/c1ccc(CN(CCO)CCc2c[nH]c3ccccc23)cc1</smiles><smiles></smiles><smiles>O=C(/C=C/c1cccc(S(=O)(=O)Nc2ccccc2)c1)NO</smiles>

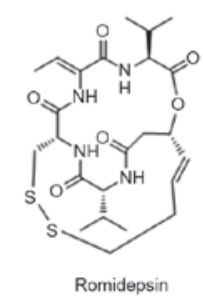<smiles>O=C(NCc1ccc(Cc2cccnn2)cc1)OCc1ccccn1</smiles><smiles>CCCCNc1ccccc1NC(=O)CC</smiles><smiles>CCCC(CCC)C(=O)O</smiles><smiles>COC(=O)CCCc1ccccc1</smiles><smiles>NC(=O)C1CCCc2c1[nH]c1ccc(Cl)cc21</smiles><smiles></smiles><smiles>CCCCc1nc2cc(/C=C/C(=O)NO)ccc2n1CCN(CC)CC</smiles><smiles>COC1=Cc2cc(OCCCN3CCCC3)ccc2N=C(C2CCCCC2)N1NC1CCN(C(C)C)CC1</smiles><smiles>CCC(C)n1cc(C)c2c(C(=O)NCc3c(C)cc(C)[nH]c3=O)cc(-c3ccc(N4CCNCC4)nc3)cc21</smiles>

EX-527

Cambinol

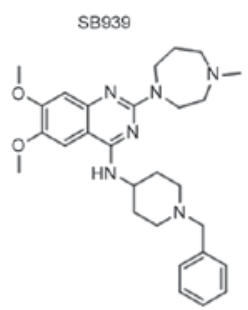

UNC0638

GSK126<smiles>CC(C)(C)CN(CCCCc1nc2cc(C(C)(C)C)ccc2[nH]1)CC1OC(n2cnc3c(N)ncnc32)C(O)C1O</smiles>

EPZ5676<smiles>O=C(/C=C/c1ccc2nc(NCCN3CCCCC3)c(NCCN3CCCCC3)nc2c1)NO</smiles>

$1-7 a b$

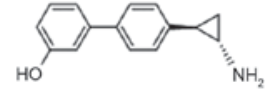

OG-L002

Figure 1. The structural features of promising epigenetic inhibitors.

bipolar mania and migraine prophylaxis previously (65). In 1996, Cinatl et al (66), reported the inhibiting effect of VPA on $\mathrm{N}$-myconco protein expression in human neuroblastoma cells, suggesting that VPA may have anticancer properties. In the past few decades, great effort has been made to study its epigenetic mechanism in various types of cancer, the majority of which focused on transcriptionally activating chromatin structures (67). Recently a phase I/II clinical trial headed by 
Iwahashi et al (68) demonstrated that S-1 (an oral fluoropyrimidine derivative consisting of the 5-fluorouracil prodrug tegafur combined with VPA for patients with pancreatobiliary tract cancer, had a manageable safety profile and preliminary antitumor activity. Sugimoto et al (69), reported that combined VPA with PEG-interferon (IFN)- $\alpha$ increased caspase-3/7 activity, induced IFN $-\alpha$ and $-\beta$ receptor subunit (IFNAR)1 and IFNAR 2 expression and increased the expression levels of IFN- $\alpha$ receptor and IFN regulatory factor 8 in pancreatic cancer, which revealed that VPA may be useful for the treatment of pancreatic cancer via enhancing the function of IFN- $\alpha$.

\section{Novel drug exploration using the old-fashioned 'Drug repositioning' method}

Increasing interest has been drawn to the idea of "drug repositioning'. Although it is a costly approach to novel drug development, the clinical value is low as the majority of the drugs have not passed the phase I trial. Therefore, certain existing drugs have been re-examined (70). A typical and successful example is Viagra, which had high expectations for use in the treatment of cardiovascular disease, but serves a role in the treatment of male sexual dysfunction. Another example is vorinostat, which was initially designed for cutaneous T-cell lymphoma but facilitated a breakthrough in HIV treatment by disturbing HIV's latency in stationary phase patients (71). Due to the potential effects and characteristics of targeted treatment for epigenetic-associated disease, epigenetic drugs are making progress and attracting attention for cancer therapy (72). The FDA approved the aforementioned epigenetic drugs, including the DNMT inhibitors azacitidine and decitabine, which were revealed to be effective in myelody splastic syndrome therapy (73). The HDAC inhibitors, vorinostat, romidepsin and belinostat, also acquired recognition in the treatment of cutaneous and peripheral $\mathrm{T}$ cell lymphoma (74). Emerging evidence demonstrated that azacitidine and decitabine also possessed anticancer effects on liver cancer, pancreatic cancer and breast cancer cells (75). It is reasonable to speculate that combining azacitidine and decitabine with other anticancer drugs, including platinum compounds and monoclonal antibodies may produce a stronger anticancer effect (76). Furthermore, vorinostat and romidepsin were also popular for gastric and lung cancer therapy $(77,78)$. Novel drug development also requires investigation using cutting-edge technology, including gene sequencing.

Sanger sequencing, first-generation sequencing that markedly impacted gene research has now evolved into next generation sequencing (NGS), which has a lower cost, higher speed and improved throughput. Recently, an epigenetic study used NGS and achieved a novel understanding of ependymoma in children. The previous study investigated DNA methylation patterns and defined a tumor $\mathrm{CpG}$ island methylator phenotype for infant nervous system malignancy, using whole genome sequencing and whole-exome sequencing (79). They revealed that the development of posterior fossa ependymomas group A (PFA), which had a poor prognosis, occurred primarily in infants and was associated with epigenetic modifications. The PFA exhibits an increased number of methylated $\mathrm{CpG}$ sites, an increased number of genes with $\mathrm{CpG}$ methylation and an increased number of genes that are transcriptionally silenced by $\mathrm{CpG}$ hypermethylation in tumor development and maintenance. The in vivo data demonstrated that treatment with decitabine and Gsk343 is able to attenuate the proliferation of PFA cells. This may further support the concept of 'drug repositioning'. Widely applicable in modern cancer clinical research (80), NGS has begun to elucidate the underlying epigenetic mechanisms; however, there is a large amount of data. Methodological improvement is required for convenient clinical application.

\section{Summary}

Epigenetics provides a molecular and etiological mechanism for the incidence of malignant cancer. Early ectogenic exposure can program later life physiology and adult onset disease due to the replication of the epigenome during somatic cell mitosis, during which 'epigenetic transgenerational inheritance' initiates. Although an increasing number of approved antitumor drugs have emerged, the outcomes of clinical trials have been unsatisfactory. This may be due to the lack of specificity and the combination with environmental exposure. In view of the critical roles of ectogenic cues on tumorigenesis, comprehensive analysis and treatment is required for early diagnosis, standardized and personalized treatment. The presence of epigenetic factors is associated with gene abnormality in premalignant cancer, and its potential reversibility indicated that epigenetic alterations may be promising biomarkers and potential novel mechanism-based strategies for tumor early diagnosis and treatment.

Previous clinical trials revealed that first generation inhibitors, including DNMTs and HDACs, have been observed to have limited utility due to toxicity and off-target effects. However, second generation compounds have been suggested to have more promise. These clinical agents have greater selectivity for their molecular target and may be a robust driver or key mediator at safe doses in malignancies. Additionally, drug repositioning still requires further enhancement and study. The improvement of epigenetic therapeutic strategies needs to be combined with cytotoxic factors, immunotherapy, targeted kinase inhibitors, NSG and the possible environmental cues.

\section{Acknowledgements}

The present study was supported by the National Natural Science Fund of China (grant nos. 31570509 and 81702326), the Gansu Province Science Foundation for Distinguished Young Scholars (grant no. 1606RJDA317) and Science and Technology Program of Lanzhou City (grant no. 2015-3-93).

\section{References}

1. Skinner MK, Manikkam M and Guerrero-Bosagna C: Epigenetic transgenerational actions of environmental factors in disease etiology. Trends Endocrinol Metab 21: 214-222, 2010.

2. Lopez-Ramirez MA and Nicoli S: Role of miRNAs and epigenetics in neural stem cell fate determination. Epigenetics 9: 90-100, 2014

3. Graça I, Pereira-Silva E, Henrique R, Packham G, Crabb SJ and Jerónimo C: Epigenetic modulators as therapeutic targets in prostate cancer. Clin Epigenetics 8: 98, 2016.

4. Do C, Shearer A, Suzuki M, Terry MB, Gelernter J, Greally JM and Tycko B: Genetic-epigenetic interactions in cis: A major focus in the post-GWAS era. Genome Biol 18: 120, 2017. 
5. Shukla SD and Lim RW: Epigenetic effects of ethanol on the liver and gastrointestinal system. Alcohol Res 35: 47-55, 2013.

6. Rothbart SB and Strahl BD: Interpreting the language of histone and DNA modifications. Biochim Biophys Acta 1839: 627-643, 2014.

7. Wilkins BJ, Rall NA, Ostwal Y, Kruitwagen T, Hiragami-Hamada K, Winkler M, Barral Y, Fischle W and Neumann H: A cascade of histone modifications induces chromatin condensation in mitosis. Science 343: 77-80, 2014.

8. Tracey R, Manikkam M, Guerrero-Bosagna C and Skinner MK: Hydrocarbons (jet fuel JP-8) induce epigenetic transgenerational inheritance of obesity, reproductive disease and sperm epimutations. Reprod Toxicol 36: 104-116, 2013.

9. Heijmans BT, Tobi EW, Stein AD, Putter H, Blauw GJ, Susser ES Slagboom PE and Lumey LH: Persistent epigenetic differences associated with prenatal exposure to famine in humans. Proc Natl Acad Sci USA 105: 17046-17049, 2008.

10. Perera F, Tang WY, Herbstman J, Tang D, Levin L, Miller R and Ho SM: Relation of DNA methylation of 5'-CpG island of ACSL3 to transplacental exposure to airborne polycyclic aromatic hydrocarbons and childhood asthma. PLoS One 4: e4488, 2009.

11. Novikova SI, He F, Bai J, Cutrufello NJ, Lidow MS and Undieh AS: Maternal cocaine administration in mice alters DNA methylation and gene expression in hippocampal neurons of neonatal and prepubertal offspring. PLoS One 3: e1919, 2008

12. Jiménez-Chillarón JC, Nijland MJ, Ascensão AA, Sardão VA, Magalhães J, Hitchler MJ, Domann FE and Oliveira PJ: Back to the future: Transgenerational transmission of xenobiotic-induced epigenetic remodeling. Epigenetics 10: 259-273, 2015

13. Zhang Y: Detection of epigenetic aberrations in the development of hepatocellular carcinoma. Methods Mol Biol 1238: 709-731, 2015

14. Tian Y, Yang W, Song J, Wu Y and Ni B: Hepatitis B virus X protein-induced aberrant epigenetic modifications contributing to human hepatocellular carcinoma pathogenesis. Mol Cell Biol 33: 2810-2816, 2013.

15. Ryu HW, Lee DH, Won HR, Kim KH, Seong YJ and Kwon SH: Influence of toxicologically relevant metals on human epigenetic regulation. Toxicol Res 31: 1-9, 2015.

16. Khan D and Ahmed SA: Epigenetic regulation of non-lymphoid cells by Bisphenol A, a model endocrine disrupter: Potential implications for immunoregulation. Front Endocrinol (Lausanne) 6: 91, 2015.

17. Guerrero-Bosagna $\mathrm{C}$ and Skinner MK: Environmentally induced epigenetic transgenerational inheritance of phenotype and disease. Mol Cell Endocrinol 354: 3-8, 2012.

18. Godfrey KM, Costello PM and Lillycrop KA: The developmental environment, epigenetic biomarkers and long-term health. J Dev Orig Health Dis 6: 399-406, 2015.

19. Jirtle RL and Skinner MK: Environmental epigenomics and disease susceptibility. Nat Rev Genet 8: 253-262, 2007.

20. Dippold RP, Vadigepalli R, Gonye GE, Patra B and Hoek JB: Chronic ethanol feeding alters miRNA expression dymanics during liver regeneration. Alcohol Clin Exp Res 37: E59-E69, 2013.

21. Pogribny IP and Rusyn I: Role of epigenetic aberrations in the development and progression of human hepatocellular carcinoma. Cancer Lett 342: 223-230, 2014.

22. Wei X, Xiang T, Ren G, Tan C, Liu R, Xu X and Wu Z: miR-101 is down-regulated by the hepatitis $B$ virus $X$ protein and induces aberrant DNA methylation by targeting DNA methyltransferase 3A. Cell Signal 25: 439-446, 2013.

23. Dhanak D and Jackson P: Development and classes of epigenetic drugs for cancer. Biochem Biophys Res Commun 455: 58-69, 2014

24. Wang $Z$ and Patel DJ: Small molecule epigenetic inhibitors targeted to histone lysine methyltransferases and demethylases. Q Rev Biophys 46: 349-373, 2013.

25. Enjuanes A, Albero R, Clot G, Navarro A, Beà S, Pinyol M Martín-Subero JI, Klapper W, Staudt LM, Jaffe ES, et al: Genomewide methylation analyses identify a subset of mantle cell lymphoma with a high number of methylated CpGs and aggressive clinicopathological features. Int J Cancer 133 2852-2863, 2013

26. Müller AM and Florek M: 5-Azacytidine/5-Azacitidine. Recent Results Cancer Res 201: 299-324, 2014.

27. Momparler RL: Epigenetic therapy of cancer with 5-aza-2'-deoxycytidine (decitabine). Semin Oncol 32: 443-451, 2005.

28. Zhao Q, Fan J, Hong W, Li L and Wu M: Inhibition of cancer cell proliferation by 5-fluoro-2'-deoxycytidine, a DNA methylation inhibitor, through activation of DNA damage response pathway. Springerplus 1: 65, 2012.
29. Marquez VE, Kelley JA, Agbaria R, Ben-Kasus T, Cheng JC, Yoo CB and Jones PA: Zebularine: A unique molecule for an epigenetically based strategy in cancer chemotherapy. Ann N Y Acad Sci 1058: 246-254, 2005.

30. Srivastava P, Paluch BE, Matsuzaki J, James SR, Collamat-Lai G, Taverna P, Karpf AR and Griffiths EA: Immunomodulatory action of the DNA methyltransferase inhibitor SGI-110 in epithelial ovarian cancer cells and xenografts. Epigenetics 10: 237-246, 2015.

31. Agarwal S, Amin KS, Jagadeesh S, Baishay G, Rao PG, Barua NC, Bhattacharya S and Banerjee PP: Mahanine restores RASSF1A expression by down-regulating DNMT1 and DNMT3B in prostate cancer cells. Mol Cancer 12: 99, 2013.

32. Dueñas-Gonzalez A, Coronel J, Cetina L, González-Fierro A, Chavez-Blanco A and Taja-Chayeb L: Hydralazine-valproate: A repositioned drug combination for the epigenetic therapy of cancer. Expert Opin Drug Metab Toxicol 10: 1433-1444, 2014.

33. Gao Z, Xu Z, Hung MS, Lin YC, Wang T, Gong M, Zhi X, Jablons DM and You L: Procaine and procainamide inhibit the Wnt canonical pathway by promoter demethylation of WIF-1 in lung cancer cells. Oncol Rep 22: 1479-1484, 2009.

34. Rilova E, Erdmann A, Gros C, Masson V, Aussagues Y, Poughon-Cassabois V, Rajavelu A, Jeltsch A, Menon Y, Novosad N, et al: Design, synthesis and biological evaluation of 4-amino-N-(4-aminophenyl) benzamide analogues of quinoline-based SGI-1027 as inhibitors of DNA methylation. ChemMedChem 9: 590-601, 2014.

35. Ramasamy TS, Ayob AZ, Myint HH, Thiagarajah S and Amini F: Targeting colorectal cancer stem cells using curcumin and curcumin analogues: Insights into the mechanism of the therapeutic efficacy. Cancer Cell Int 15: 96, 2015.

36. Graça I, Sousa EJ, Baptista T, Almeida M, Ramalho-Carvalho J, Palmeira C, Henrique R and Jerónimo C: Anti-tumoral effect of the non-nucleoside DNMT inhibitor RG108 in human prostate cancer cells. Curr Pharm Des 20: 1803-1811, 2014.

37. Lee E, Jeong KW, Jnawali HN, Shin A, Heo YS and Kim Y: Cytotoxic activity of 3,6-dihydroxyflavone in human cervical cancer cells and its therapeutic effect on c-Jun N-terminal kinase inhibition. Molecules 19: 13200-13211, 2014.

38. Chakrabarty S, Ganguli A, Das A, Nag D and Chakrabarti G: Epigallocatechin-3-gallate shows anti-proliferative activity in HeLa Cells targeting tubulin-microtubule equilibrium. Chem Biol Interact 242: 380-389, 2015.

39. Shukla S and Gupta S: Apigenin: A promising molecule for cancer prevention. Pharm Res 27: 962-978, 2010.

40. Qiang W, Jin T, Yang Q, Liu W, Liu S, Ji M, He N, Chen C, Shi B and Hou P: PRIMA-1 selectively induces global DNA demethylation in p53 mutant-type thyroid cancer cells. J Biomed Nanotechnol 10: 1249-1258, 2014.

41. Spagnuolo C, Russo GL, Orhan IE, Habtemariam S, Daglia M, Sureda A, Nabavi SF, Devi KP, Loizzo MR, Tundis R and Nabavi SM: Genistein and cancer: Current status, challenges, and future directions. Adv Nutr 6: 408-419, 2015.

42. Wyrębska A, Gach K and Janecka A: Combined effect of parthenolide and various anti-cancer drugs or anticancer candidate substances on malignant cells in vitro and in vivo. Mini Rev Med Chem 14: 222-228, 2014.

43. Minami J, Suzuki R, Mazitschek R, Gorgun G, Ghosh B, Cirstea D, Hu Y, Mimura N, Ohguchi H, Cottini F, et al: Histone deacetylase 3 as a novel therapeutic target in multiple myeloma. Leukemia 28: 680-689, 2014.

44. Richon VM: Targeting histone deacetylases: Development of vorinostat for the treatment of cancer. Epigenomics 2: 457-465, 2010.

45. Li X, Zhang J, Xie Y, Jiang Y, Yingjie Z and Xu W: Progress of HDAC inhibitor panobinostat in the treatment of cancer. Curr Drug Targets 15: 622-634, 2014.

46. Wang X, Xu J, Wang H, Wu L, Yuan W, Du J and Cai S: Trichostatin A, a histone deacetylase inhibitor, reverses epithelial-mesenchymal transition in colorectal cancer SW480 and prostate cancer PC3 cells. Biochem Biophys Res Commun 456: 320-326, 2015

47. Ganai SA: Strategy for enhancing the therapeutic efficacy of histone deacetylase inhibitor dacinostat: The novel paradigm to tackle monotonous cancer chemoresistance. Arch Pharm Res: 2015 (Epub ahead of print)

48. Xing LF, Wang DT, Yang Y and Pan SY: Effect of HDAC-6 on PD cell induced by lactacystin. Asian Pac J Trop Med 8: 855-859, 2015. 
49. Kirschbaum MH, Foon KA, Frankel P, Ruel C, Pulone B, Tuscano JM and Newman EM: A phase 2 study of belinostat (PXD101) in patients with relapsed or refractory acute myeloid leukemia or patients over the age of 60 with newly diagnosed acute myeloid leukemia: A California Cancer Consortium study. Leuk Lymphoma 55: 2301-2304, 2014.

50. Bertino EM and Otterson GA: Romidepsin: A novel histone deacetylase inhibitor for cancer. Expert Opin Investig Drugs 20: 1151-1158, 2011.

51. Ruiz R, Raez LE and Rolfo C: Entinostat (SNDX-275) for the treatment of non-small cell lung cancer. Expert Opin Investig Drugs 24: 1101-1109, 2015.

52. Duenas-Gonzalez A, Candelaria M, Perez-Plascencia C, Perez-Cardenas E, de la Cruz-Hernandez E and Herrera LA: Valproic acid as epigenetic cancer drug: Preclinical, clinical and transcriptional effects on solid tumors. Cancer Treat Rev 34: 206-222, 2008

53. Tsunedomi R, Iizuka N, Harada S and Oka M: Susceptibility of hepatoma-derived cells to histone deacetylase inhibitors is associated with ID2 expression. Int J Oncol 42: 1159-1166, 2013

54. Nielsen TK, Hildmann C, Riester D, Wegener D, Schwienhorst A and Ficner R: Complex structure of a bacterial class 2 histone deacetylase homologue with a trifluoromethylketone inhibitor. Acta Crystallogr Sect F Struct Biol Cryst Commun 63: 270-273, 2007.

55. Tao YF, Lin F, Yan XY, Gao XG, Teng F, Fu ZR and Wang ZX Galectin-9 in combination with EX-527 prolongs the survival of cardiac allografts in mice after cardiac transplantation. Transplant Proc 47: 2003-2009, 2015

56. Mahajan SS, Scian M, Sripathy S, Posakony J, Lao U, Loe TK, Leko V, Thalhofer A, Schuler AD, Bedalov A and Simon JA: Development of pyrazolone and isoxazol-5-one cambinol analogues as sirtuin inhibitors. J Med Chem 57: 3283-3294, 2014

57. Yang L, Liang Q, Shen K, Ma L, An N, Deng W, Fei Z and Liu J: A novel class I histone deacetylase inhibitor, I-7ab, induces apoptosis and arrests cell cycle progression in human colorectal cancer cells. Biomed Pharmacother 71: 70-78, 2015.

58. Eigl BJ, North S, Winquist E, Finch D, Wood L, Sridhar SS, Powers J, Good J, Sharma M, Squire JA, et al: A phase II study of the HDAC inhibitor SB939 in patients with castration resistant prostate cancer: NCIC clinical trials group study IND195. Invest New Drugs 33: 969-976, 2015.

59. Cui J, Sun W, Hao X, Wei M, Su X, Zhang Y, Su L and Liu X: EHMT2 inhibitor BIX-01294 induces apoptosis through PMAIP1-USP9X-MCL1 axis in human bladder cancer cells Cancer Cell Int 15: 4, 2015.

60. Fu L, Yan FX, An XR and Hou J: Effects of the histone methyltransferase inhibitor UNC0638 on histone H3K9 dimethylation of cultured ovine somatic cells and development of resulting early cloned embryos. Reprod Domest Anim 49: e21-e25, 2014.

61. Tiffen JC, Gunatilake D, Gallagher SJ, Gowrishankar K, Heinemann A, Cullinane C, Dutton-Regester K, Pupo GM, Strbenac D, Yang JY, et al: Targeting activating mutations of EZH2 leads to potent cell growth inhibition in human melanoma by derepression of tumor suppressor genes. Oncotarget 6 : 27023-27036, 2015

62. Horiuchi KY, Eason MM, Ferry JJ, Planck JL, Walsh CP, Smith RF, Howitz KT and Ma H: Assay development for histone methyltransferases. Assay Drug Dev Technol 11: 227-236, 2013.

63. Maes T, Mascaró C, Ortega A, Lunardi S, Ciceri F, Somervaille TC and Buesa C: KDM1 histone lysine demethylases as targets for treatments of oncological and neurodegenerative disease. Epigenomics 7: 609-626, 2015.
64. Qian S, Wang Y, Ma H and Zhang L: Expansion and functional divergence of Jumonji C-containing histone demethylases: Significance of duplications in ancestral angiosperms and vertebrates. Plant Physiol 168: 1321-1337, 2015.

65. Verrotti A, Carelli A, di Genova L and Striano P: Epilepsy and chromosome 18 abnormalities: A review. Seizure 32: 78-83, 2015

66. Cinatl J Jr, Cinatl J, Scholz M, Driever PH, Henrich D, Kabickova H, Vogel JU, Doerr HW and Kornhuber B: Antitumor activity of sodium valproate in cultures of human neuroblastoma cells. Anticancer Drugs 7: 766-773, 1996.

67. Woodworth AM and Holloway AF: The role of epigenetic regulation in transcriptional memory in the immune system. Adv Protein Chem Struct Biol 106: 43-69, 2017.

68. Iwahashi S, Utsunomiya T, Imura S, Morine Y, Ikemoto T, Arakawa Y, Saito Y, Ishikawa D and Shimada M: Effects of valproic acid in combination with $\mathrm{S}-1$ on advanced pancreatobiliary tract cancers: Clinical study phases I/II. Anticancer Res 34: 5187-5191, 2014

69. Sugimoto K, Shimada M, Utsunomiya T, Morine Y, Imura S, Ikemoto T and Iwahashi S: Valproic acid enhances the anti-tumor effect of pegylated interferon- $\alpha$ towards pancreatic cancer cell lines. Anticancer Res 34: 3403-3409, 2014.

70. Bastos LF and Coelho MM: Drug repositioning: Playing dirty to kill pain. CNS Drugs 28: 45-61, 2014.

71. Archin NM, Liberty AL, Kashuba AD, Choudhary SK, Kuruc JD, Crooks AM, Parker DC, Anderson EM, Kearney MF, Strain MC, et al: Administration of vorinostat disrupts HIV-1 latency in patients on antiretroviral therapy. Nature 487: 482-485, 2012

72. Di Costanzo A, Del Gaudio N, Migliaccio A and Altucci L: Epigenetic drugs against cancer: An evolving landscape. Arch Toxicol 88: 1651-1668, 2014.

73. Mummaneni $\mathrm{P}$ and Shord SS: Epigenetics and oncology. Pharmacotherapy 34: 495-505, 2014.

74. Glaser KB: HDAC inhibitors: Clinical update and mechanism-based potential. Biochem Pharmacol 74: 659-671, 2007.

75. Li X, Mei Q, Nie J, Fu X and Han W: Decitabine: A promising epi-immunotherapeutic agent in solid tumors. Expert Rev Clin Immunol 11: 363-375, 2015 .

76. Garrido-Laguna I, McGregor KA, Wade M, Weis J, Gilcrease W, Burr L, Soldi R, Jakubowski L, Davidson C, Morrell G, et al: A phase I/II study of decitabine in combination with panitumumab in patients with wild-type (wt) KRAS metastatic colorectal cancer. Invest New Drugs 31: 1257-1264, 2013.

77. Zhou C, Ji J, Shi M, Yang L, Yu Y, Liu B, Zhu Z and Zhang J: Suberoylanilide hydroxamic acid enhances the antitumor activity of oxaliplatin by reversing the oxaliplatin-induced Src activation in gastric cancer cells. Mol Med Rep 10: 2729-2735, 2014.

78. Karthik S, Sankar R, Varunkumar K and Ravikumar V: Romidepsin induces cell cycle arrest, apoptosis, histone hyperacetylation and reduces matrix metalloproteinases 2 and 9 expression in bortezomib sensitized non-small cell lung cancer cells. Biomed Pharmacother 68: 327-334, 2014.

79. Mack SC, Witt H, Piro RM, Gu L, Zuyderduyn S, Stütz AM, Wang X, Gallo M, Garzia L, Zayne K, et al: Epigenomic alterations define lethal CIMP-positive ependymomas of infancy. Nature 506: 445-450, 2014.

80. Tabatabaeifar S, Kruse TA, Thomassen M, Larsen MJ and Sørensen JA: Use of next generation sequencing in head and neck squamous cell carcinomas: A review. Oral Oncol 50: 1035-1040, 2014. 